\title{
Geology, Geochemistry and Radioactivity of Granitic and Volcanic Rocks at Hadarba Area, South Eastern Desert, Egypt
}

\author{
Hassan A. A. Shahin*, Masoud S. Masoud and Moustafa M. Bayoumi \\ Nuclear Materials Authority, P. O. Box 530, El-Maadi, Cairo, Egypt
}

Corresponding author email address: hassanshahin03@yahoo.com

ABSTRACT

\begin{abstract}
The present work deals with geology, geochemistry, radioactivity and tectonic environment of the granitic and volcanic rocks at Hadarba area, South Eastern Desert of Egypt. The granitic rocks comprise tonalite-granodiorite and monzogranite, while volcanic rocks include rhyolite, rhyodacite anddacite. These rocks are characterized by high concentrations of $\mathrm{SiO}_{2}, \mathrm{Na}_{2} \mathrm{O}, \mathrm{Fe}_{2} \mathrm{O}_{3}, \mathrm{~K} 2 \mathrm{O}, \mathrm{Zr}, \mathrm{Nb}$ and $\mathrm{Y}$ but low in $\mathrm{MgO}, \mathrm{CaO}, \mathrm{Cr}, \mathrm{Ni}, \mathrm{Sr}, \mathrm{Ga}$ and $\mathrm{V}$. Field studies indicate that Dokhan volcanics extrude both tonalite-granodiorite and monzogranite with sharp contact forming a thick successive sequence of laminated acid lava flows, crystal lapilli tuffs and agglomerates. They range in composition from rhyolite, rhyodacite to dacite. Shear zone comprise lines-arranged intrusions trending NE-SW direction were recorded north Gabal Hadarba and extends for about $2.3 \mathrm{~km}$ in length with a width reaches up to $\mathbf{1 0}$ meter. These lines-arranged intrusions include quartz vein, microgranite and basic dykes. These shear zones cut through monzogranite. Petrochemical studies and tectonic discrimination diagrams for the monzogranite reveal that it is classified as granite developed in the within-plate tectonic environment, while Dokhan volcanics are classified as rhyolite and dacite developed in the immature island arcs and active continental margin environments. Field radiometric measurements of these granitic and volcanic rocks reveal low uranium and thorium contents. Uranium contents range from 1.2 to $2.7 \mathrm{ppm}$ in the tonalite-granodiorite, from 1.1 to $8.5 \mathrm{ppm}$ in the monzogranite, from 1.3 to $9.3 \mathrm{ppm}$ in the Dokhan volcanic and from $1.4 \mathrm{ppm}$ to $15.4 \mathrm{ppm}$ in the felsite dyke.
\end{abstract}

Keywords: Geochemistry, granitic and volcanic rocks, Hadarba area

\section{INTRODUCTION}

Hadarba area is located in the Southern extremity of the Eastern Desert of Egypt nears the Sudan Frontier and occupies the Southern half of Elba topographic sheet (NF-37 I), scale 1:250,000. It is easily reached through the Shalatin- Halaib asphaltic road along the Red Sea Coast. It lies at a distance of about $40 \mathrm{~km}$ South of AbuRamad City. It is bounded by Latitudes $22^{\circ} 00^{\prime} 00^{\prime \prime}$ to $22^{\circ}$ $09^{\prime} 53^{\prime \prime} \mathrm{N}$ and Longitudes $36^{\circ} 27^{\prime} 50^{\prime \prime}$ to $36^{\circ} 51^{\prime} 04^{\prime \prime} \mathrm{E}$. Geomorphologically, the area is characterized by the rough Red Sea mountains, moderate isolated hills, conical low hills, wadi floors and coastal plain (Fig.1). The important mountains encountered in the area are Gabal Hadarba, Gabal Shellal, Gabal Karm Elba and Gabal O Wata and the important wadis are Wadi Shellal and Wadi Aqilhoq.
Hadarba area is underlain mainly by the granitic rocks and Dokhan volcanics. The granitic rocks are represented by tonalite-granodiorite and monzogranite. Dokhan volcanic forms a successive sequence of acidic lava flows, ash tuffs, crystal lapilli tuffs and agglomerates. Many studies have been carried out on the petrography and geochemistry of the Dokhan volcanics, (Basta et al., (1980); Stern and Gottfried, (1986); El Gaby et al., (1989); Abdel Rahman, (1996); Mohamed et al., (2000); Eliwa, (2000); Moghazi, (2003); El Sayed et al., (2004) ;Eliwa et.al (2006) ; Khalaf (2010) and Alaabed and El Tokhi (2014).These authors show that the Dokhan volcanics have medium- to high-K calc-alkaline affinities. The geotectonic interpretation of the Dokhan volcanics is still controversial, especially whether they have been 


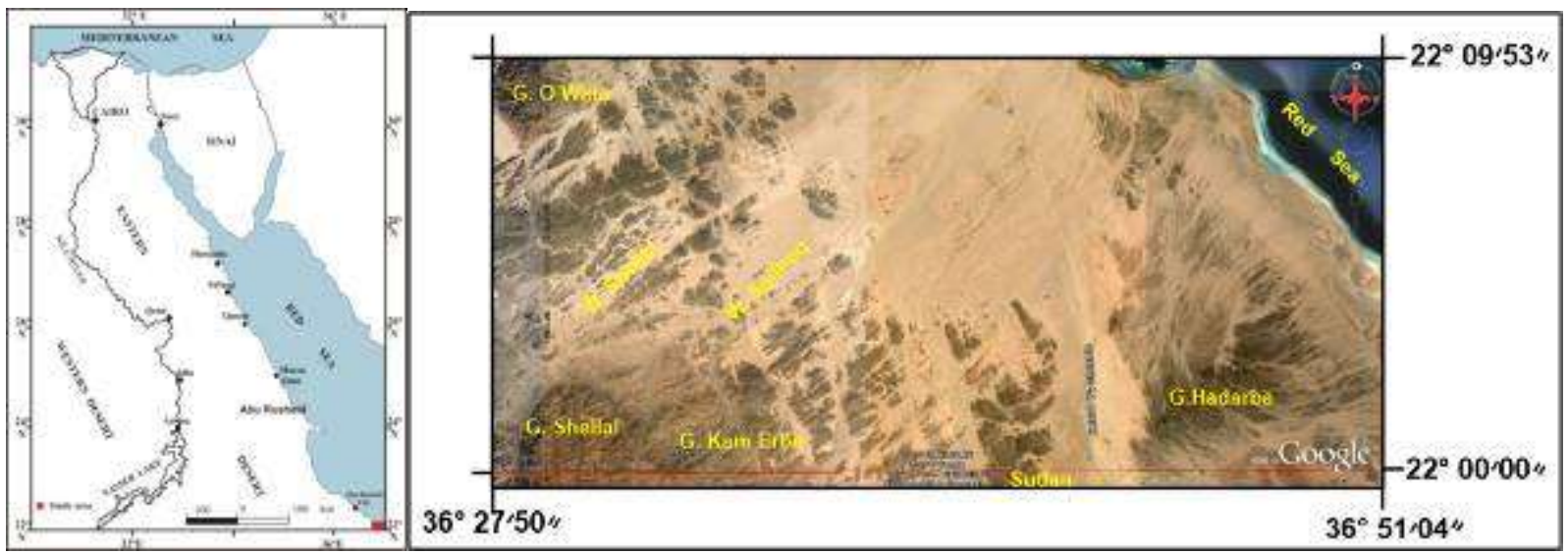

Figure1. Location map and Google image for Hadarba area ( $\square$ ).

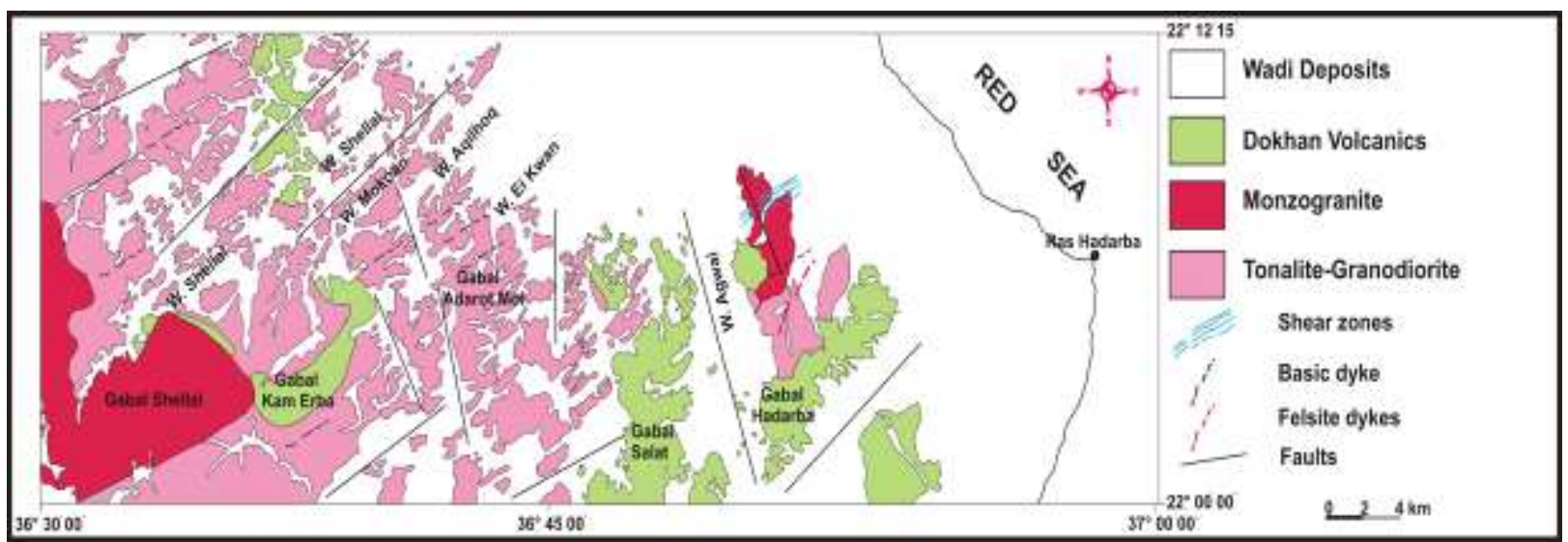

Figure2. Geologic map for Gabal Hadarba area

formed (1) in a subduction environment (Hassan and Hashad, 1990; El Gaby et al., 1990), (2) in association with extension after crustal thickening (Stern et al., 1984, 1988; Stern, 1994; Fritz et al., 1996),(3) during transition between subduction and extension (Ressetar and Monard, 1983; Mohamed et al., 2000).

The study area was earlier studied by Ball (1912), who studied the topography and geology of the South Eastern Desert, Egypt. Hume (1934) studied the fundamental Precambrian rocks of Egypt and Sudan. Geological Survey of Egypt (1999) prepared geologic map on scale 1:250.000 for the basement rocks of Gabal Elba Quadrangle, Egypt between Latitude $22^{\circ} 00^{\prime}-23^{\circ}$ 00'. Hussein (1977) studied the geology of Halaib area at the northern Red Sea Hills with reference to the Sol Hamed basic complex. Fitches (1983) studied the Late Proterozoic ophiolite of Sol Hamed, NE Sudan. El Alfy et.al. (1994) prepared geochemical exploration of Elba Gerf area South Eastern Desert. Nasr and Youssef (1995) studied the Tertiary alkaline rocks in Gabal Elba area South Eastern Desert. Khaliad et.al. (1997) studied the results of geological, mineralogical and geochemical exploration of Gebel Elba. Nasr and El Sherbeni (1998) studied the Dokhan volcanics in the Halaib area South
Eastern Desert. He concluded that a new occurrence of Dokhan volcanics in Halaib area is presented by a thick succession of surface and subsurface acid volcanics. Omar et.al. (1998) prepared geochemical map sheet No. 36 NE L 1,2,3 of Qash Amir area, South Eastern Desert, Egypt.

The chief aim of the present paper is elucidating geology, geochemistry and radioactivity of the granitic and volcanic rocks at Hadarba area, South Eastern Desert, Egypt.

\section{GEOLOGIC SETTING}

The area of study is covered by a succession of Neoproterozoic Pan-African (Precambrian) basement rocks including intrusive and extrusive assemblages. The intrusive rocks comprise tonalite-granodiorite and monzogranite. The extrusive rocks include Dokhan volcanics which are mainly exposed as successive sequences of lava flows, tuffs, and agglomerates, approximately $5 \mathrm{~km}$ thick and constitute moderately high mountainous ridges (Fig.2). These rocks are cut by numerous acidic, intermediate and dolerite dykes. 

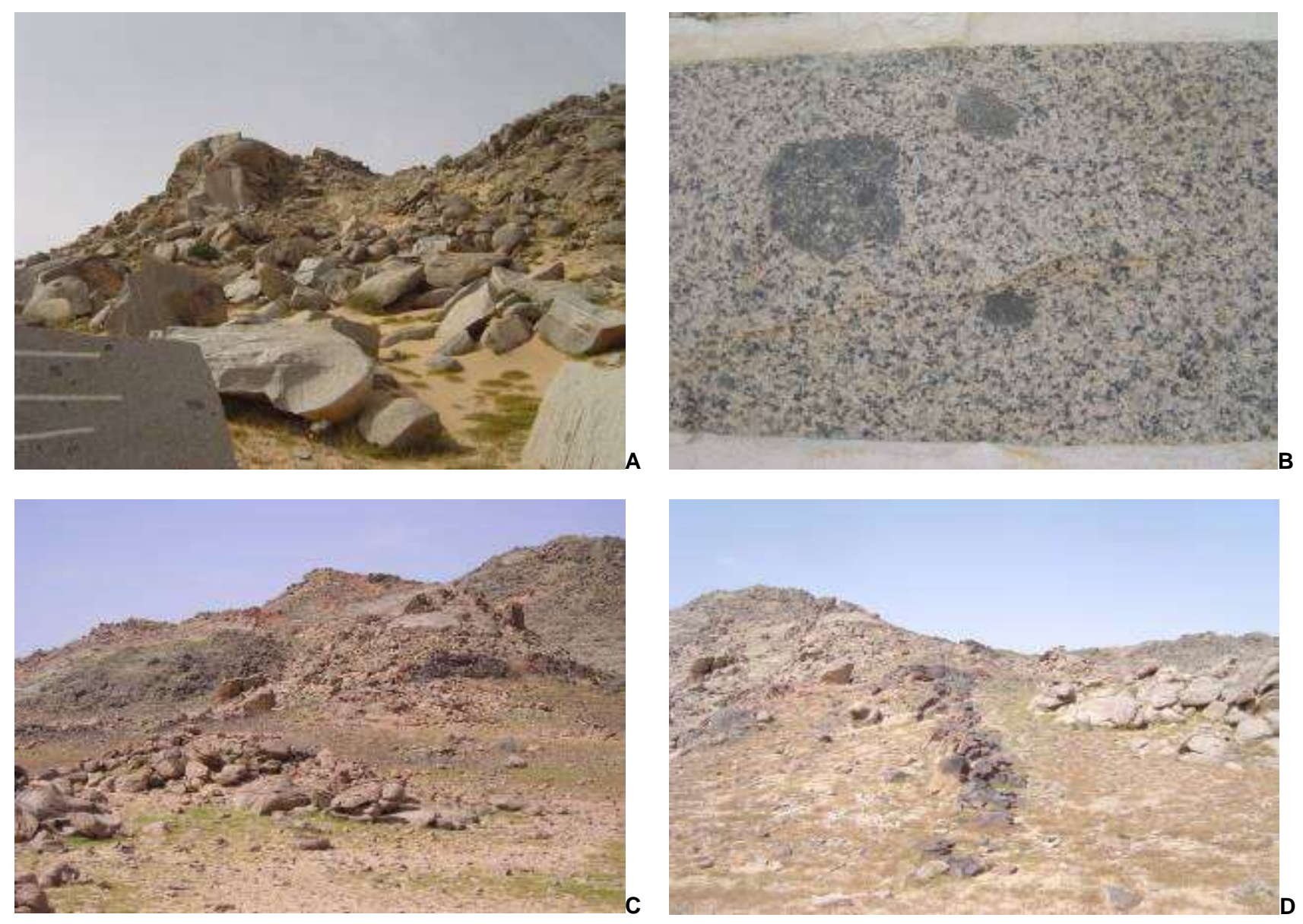

Figure3. Field Photographs for granitoid rocks,

A. Blocks of tonalite-granodiorite in Hadarba quarry. Looking west,

B. Close view showing subrounded mafic rich xenoliths in tonalite-granodiorite. Looking South,

C. Monzogranite extruded by Dokhan volcanics. Looking South east,

D. Felsite dyke cuts in the monzogranite. Looking South

\section{INTRUSIVE ROCKS}

These rocks include both tonalite-granodiorite and monzogranite.

\section{Tonalite - granodiorite}

Tonalite - granodiorite rocks are widespread rock unites encountered in the area. These rocks are well represented at Wadi Aqilhoq and north Gabal Hadarba. They form NE elongated belts of low to moderate relief, weathered, exfoliated and composed essentially of quartz, plagioclase, K-feldspar, biotite and minor hornblende. These rock contained subrounded to subangular mafic rich xenolithic bodies up to $20 \mathrm{~cm}$ in diameter (Fig.3A and B).These rocks are extruded by Dokhan volcanics and intruded by monzogranite. The tonalite-granodiorite are invaded by dyke swarms trending E-W and NW-SE mainly felsite and rhyolite porphyry.

\section{Monzogranite}

The monzogranite well represented as low, moderate and high hills at Gabal Shellal and north Gabal Hadarba (Fig.3C). This rock is pale pink to pink color, medium to coarse grained and composed of quartz, k-feldspar, biotite and rare muscovite. Field study indicates that the monzogranite intrudes tonalite- granodiorite and extruded by Dokhan volcanic and cross cut by swarms of felsite and acidic dykes (Fig.3D).

\section{EXTRUSIVE ROCKS}

They are represented by Dokhan volcanics.

\section{Dokhan volcanics}

Dokhan volcanics are widely distributed and exposed as nearly N-S elongated belts at Hadarba area, which 

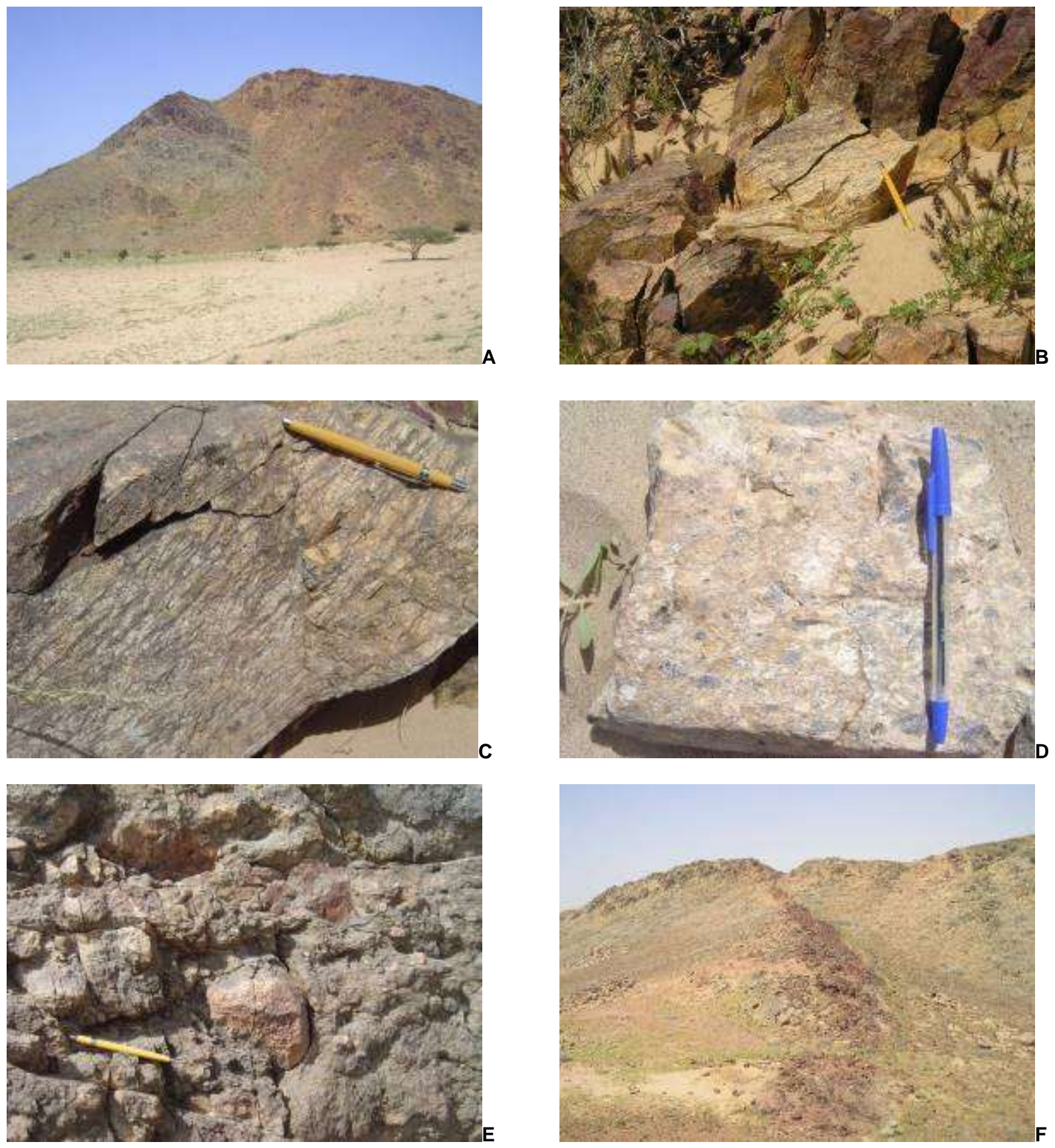

Figure4.Field Photographs for Dokhan volcanics,

A. Sequences of buff and violet rhyolite. Looking west,

B. Laminating acid lava flows. Looking South west,

C. Close view showing rhyolite follow band,

D. Crystal lapilli tuffs in Dokhan volcanics,

E. Large enclave of granitic composition in agglomerate rock. Looking South west,

F. Felsite dyke extruding in Dokhan volcanics. Looking west

occupy a large area at Wadi Hibru, Wadi Kuwan, Gabel Hadarba and Wadi Aqilhoq. These rocks are represented by successive sequences of lava flows, tuffs, and agglomerates (Fig. 4A-F). In some parts these sequences are emplaced by subhorizontal successive sheets of volcanic porphyry which are concordant to the banding. The successive lava flows range in composition from rhyolite, rhyodacite to dacite, as well as thick sequences of welded ash flow tuffs, crystal tuffs, lithic lapilli tuffs and agglomerates. Porphyritic texture is well developed in the most of these rocks. Field study indicates that Dokhan volcanics are extruded in the tonalite-granodiorite 


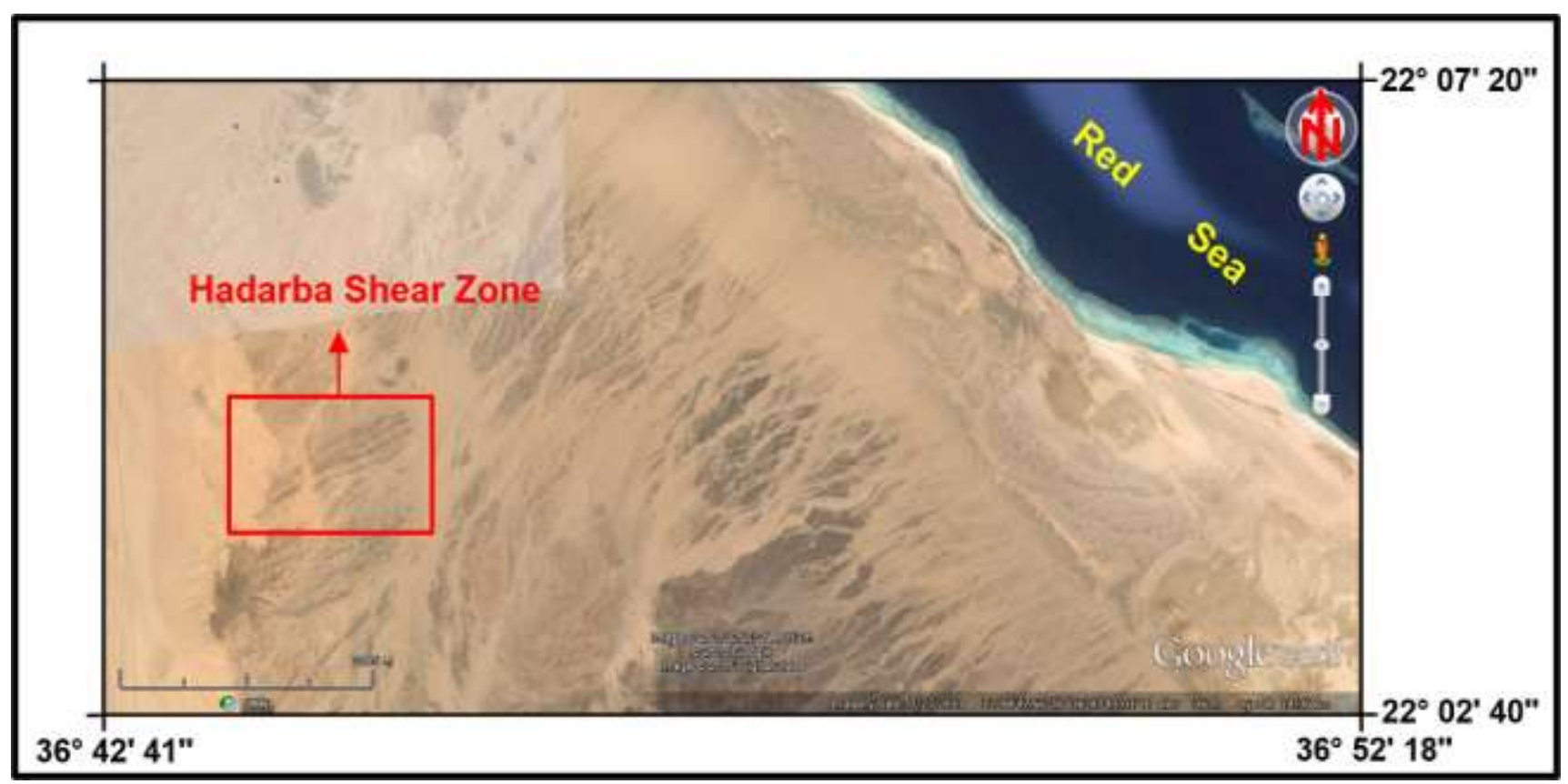

Figure 5A. General view of Google image for Hadarba shear zones, South Eastern Desert, Egypt

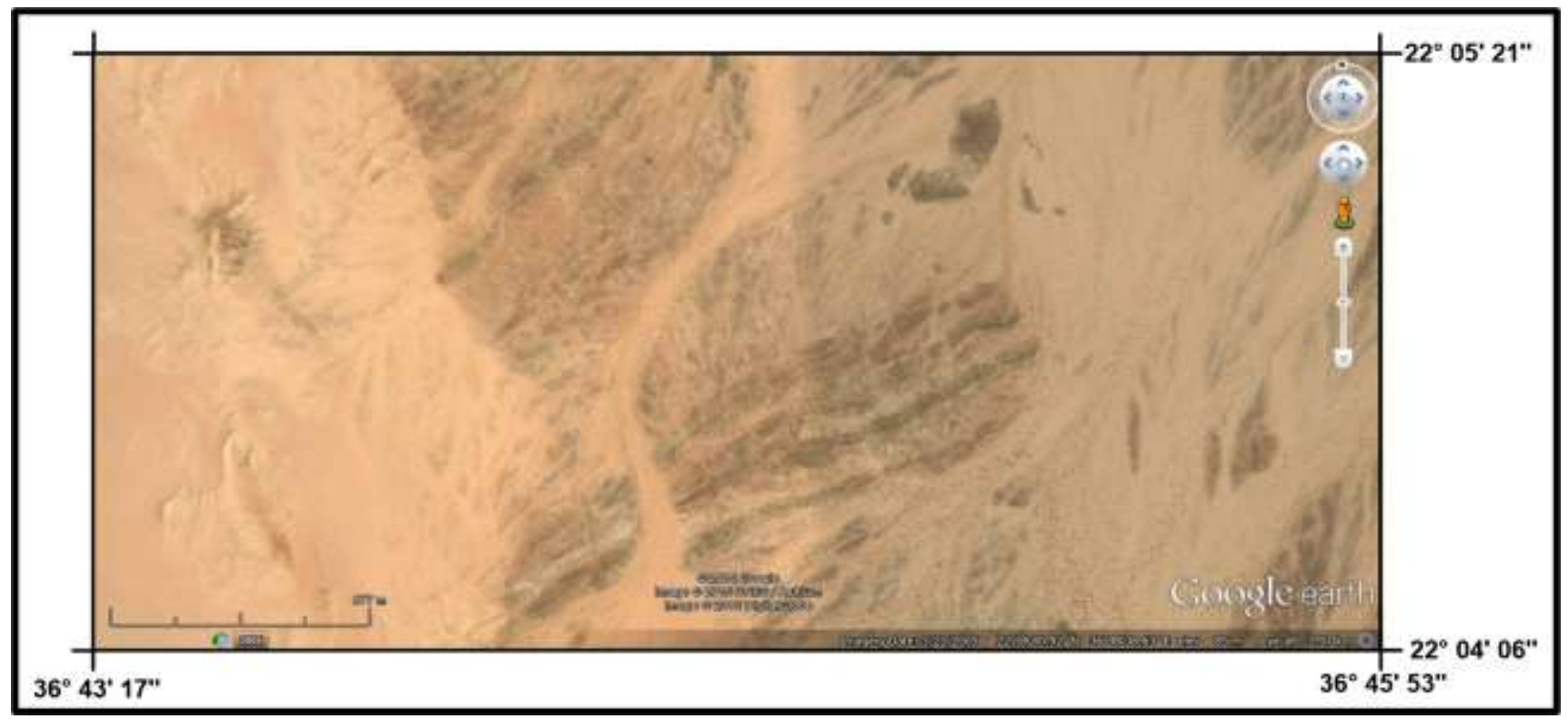

Figure 5B. Close up view Google image for Hadarba shear zone, South Eastern Desert, Egypt

and biotite- muscovite granite as well as felsite, acidic and basic dyke swarms (Fig. 4F). These volcanic rocks are relate to the Feirani volcanics of the South Sinai Egypt by Abu El-Leil et al., (1990).

\section{Hadarba shear zones}

Hadarba shear zone comprise line-arranged intrusions trending to the NE-SW direction and extend for about 2.3 $\mathrm{km}$ length with a width reaching up to 6 to 10 meters for each one (Fig.5A and B). These line-arranged intrusions include microgranite dyke, basic dyke and quartz vein cut through monzogranite (Fig.6). The quartz veins are cutting through the monzogranite in NE-SW direction. It occurs as massive, milky quartz and in some parts it is fractured and jointed. Their thickness ranges from 5 to 10 meters and extends for about 900 meters lenght. This quartz veins have uranium content ranges from 0.2 to 0.8 $\mathrm{ppm}$. The microgranite dykes are mainly injected along the NE-SW direction. These dykes are whitish buff to buff in color, 
Shahin et al. 043

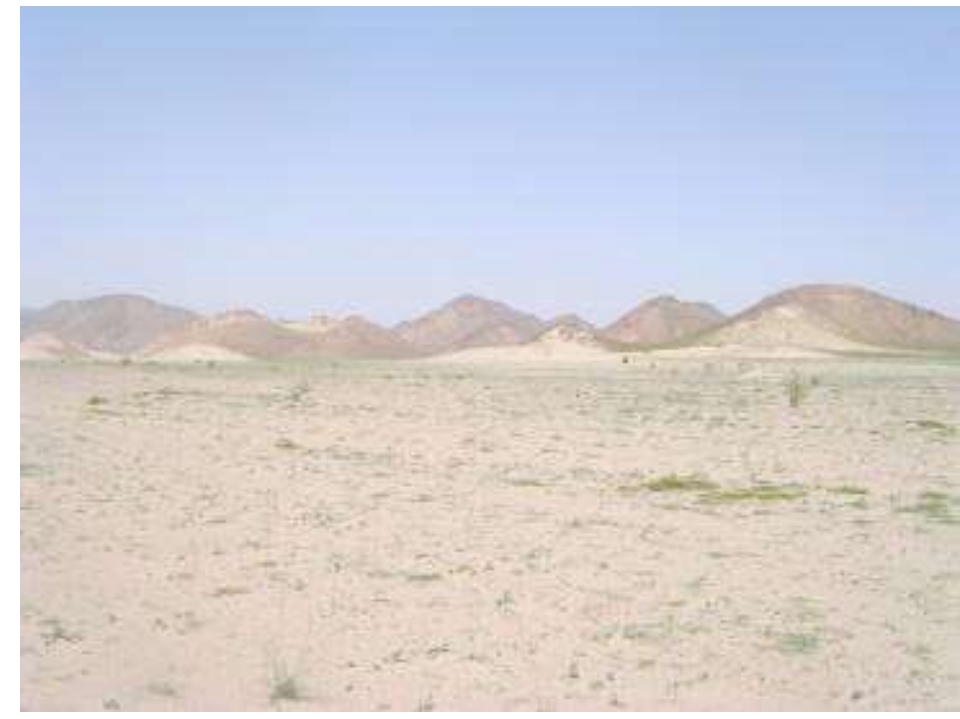

Figure6. Lines-arranged intrusions include microgranite dyke, basic dyke and quartz vein at Hadarba Shear zone
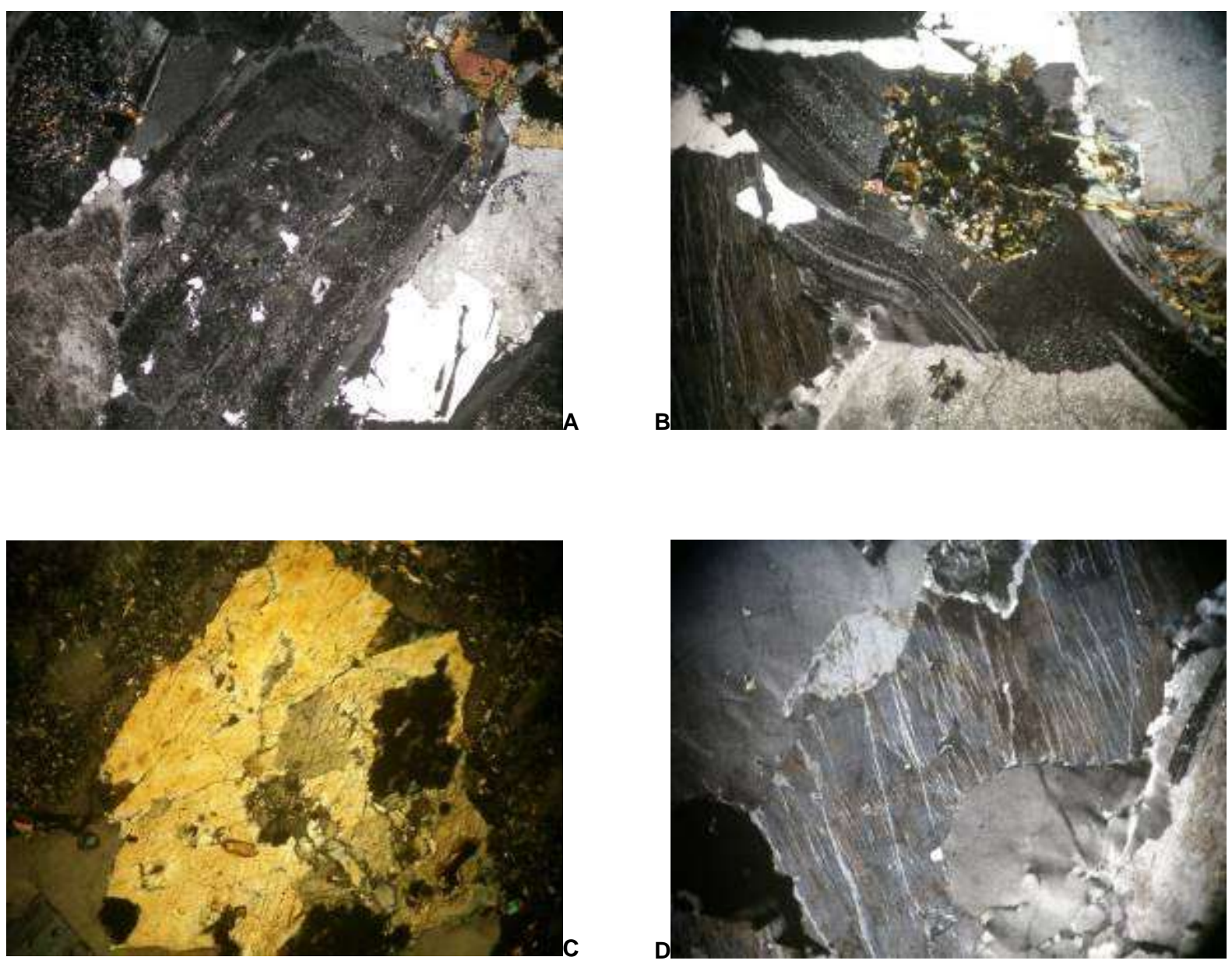
044 Int. Res. J. Geol. Min.

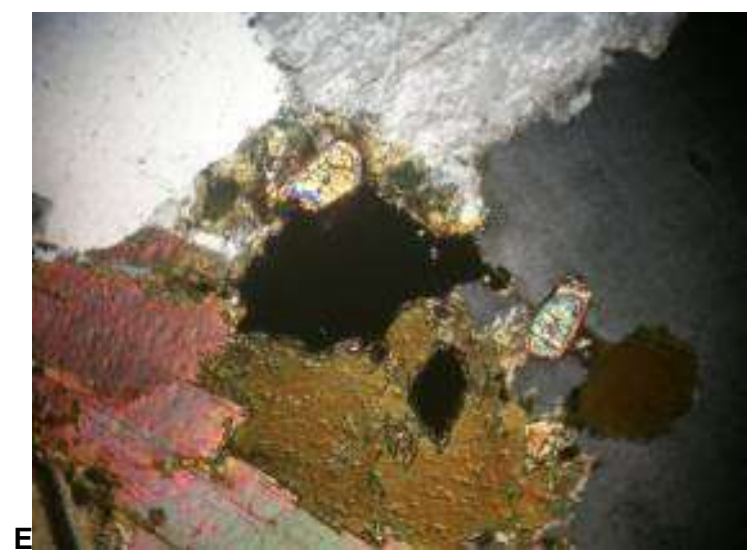

Figure 7. Microscopic investigation of the studied granitoid rocks,

A. Plagioclase exhibiting zonal structure in tonalite-granodiorite, C.N. X10

B. Chlorite and eipdote inclusion in folded plagioclase in tonalite-granodiorite, C.N. X20

C. Hornblende enclosed zircon in tonalite-granodiorite, C.N. X20

D. String perthite corroded by quartz in monzogranite, C.N. X20

E. Metamict zircon associated with perthite and biotite in monzogranite, C.N. X40

leucocratic, fine grained, massive and equigranular of these dykes varies from $1 \mathrm{~m}$ to $6 \mathrm{~m}$ and extends for more than 2300 meters in the NE-SW direction. These dykes have uranium content ranges from 1.9 to $4.6 \mathrm{ppm}$.

Basic dykes follow the main fault plain with nearly vertical dip. They extend along the NE-SW shear zone for more than $2.3 \mathrm{~km}$ long with width varies from $1 \mathrm{~m}$ to $8 \mathrm{~m}$. They are dark gray to grayish green color and fine grained. These dyke have uranium content ranges from 0.3 to $4.4 \mathrm{ppm}$.

\section{PETROGRAPHY}

\section{Tonalite-granodiorite}

They are distinctly equigranular, coarse-grained of hypidiomorphic texture. Microscopically, they are composed mainly of plagioclase, quartz, alkali feldspar and hornblende. The accessory minerals are, apatite, sphene and iron oxides. Plagioclase represents the main constituent mineral in these rocks. It is represented by euhedral megacrysts up to $3.4 \times 2.1 \mathrm{~mm}$. Polysynthetic twinning and zoned plagioclase are well common (Fig.7A). Some crystals show deformation due to outer stress (Fig.7B). Quartz occurs as anhedral phenocrysts up to $5 \times 4.6 \mathrm{~mm}$. All quartz crystals are characterized by the wavy extinction due to outer stress and deformation. Alkali feldspar occurs as euhedral to subhedral megacrysts up to $2.3 \times 1.3 \mathrm{~mm}$. Most of these alkali feldspar crystals are represented by perthite, where perthite veinlets are observed. Hornblende occurs as subhedral to anhedral megacrysts up to $1.1 \times 0.6 \mathrm{~mm}$. It also occurs as small crystals filling the spaces between the plagioclase megacrysts. Most of the hornblende megacrysts enclose metmact zircon (Fig.7C).

\section{Monzogranite}

They are distinctly equigranular medium to coarse grained of hypidiomorphic texture. Microscopically, they are composed essentially of quartz, perthite, plagioclase, biotite and rare muscovite. The accessory minerals are iron oxides, apatite and zircon. Quartz occurs either as subhedral to anhedral megacrysts up to $4.8 \times 3.9 \mathrm{~mm}$ or as small crystals up to $0.1 \times 0.2 \mathrm{~mm}$. It is found in two generation, the older fills the interstices between the feldspar crystals, whereas the younger is graphically intergrowth with perthite crystals. Perthite occurs as subhedral megacrysts up to $2.6 \times 3.3 \mathrm{~mm}$. Perthitic veinlets are the most predominate type of perthite in these rocks (Fig.7D). Biotite represents the chief mafic minerals. It occurs as subhedral to anhedral crystals. These biotite crystals show pleochroism from yellow to brown color. Biotite megacrysts reach up to $1.35 \times 0.6$ $\mathrm{mm}$, while the small crystals up to $0.3 \times 0.25 \mathrm{~mm}$. They are variably altered to chlorite (Fig.7E).

\section{Dokhan volcanics}

\section{Rhyolite}

Rhyolite shows mainly porphyritic textures (Fig.8A and $B$ ). It is formed essentially by phenocrysts of quartz, plagioclase and potash feldspars (sanidine) embedded in a fine-grained groundmass of quartz and, sanidine. Chlorite, sericite and epidote are secondary mineral, whereas zircon and irono xides are accessories. 

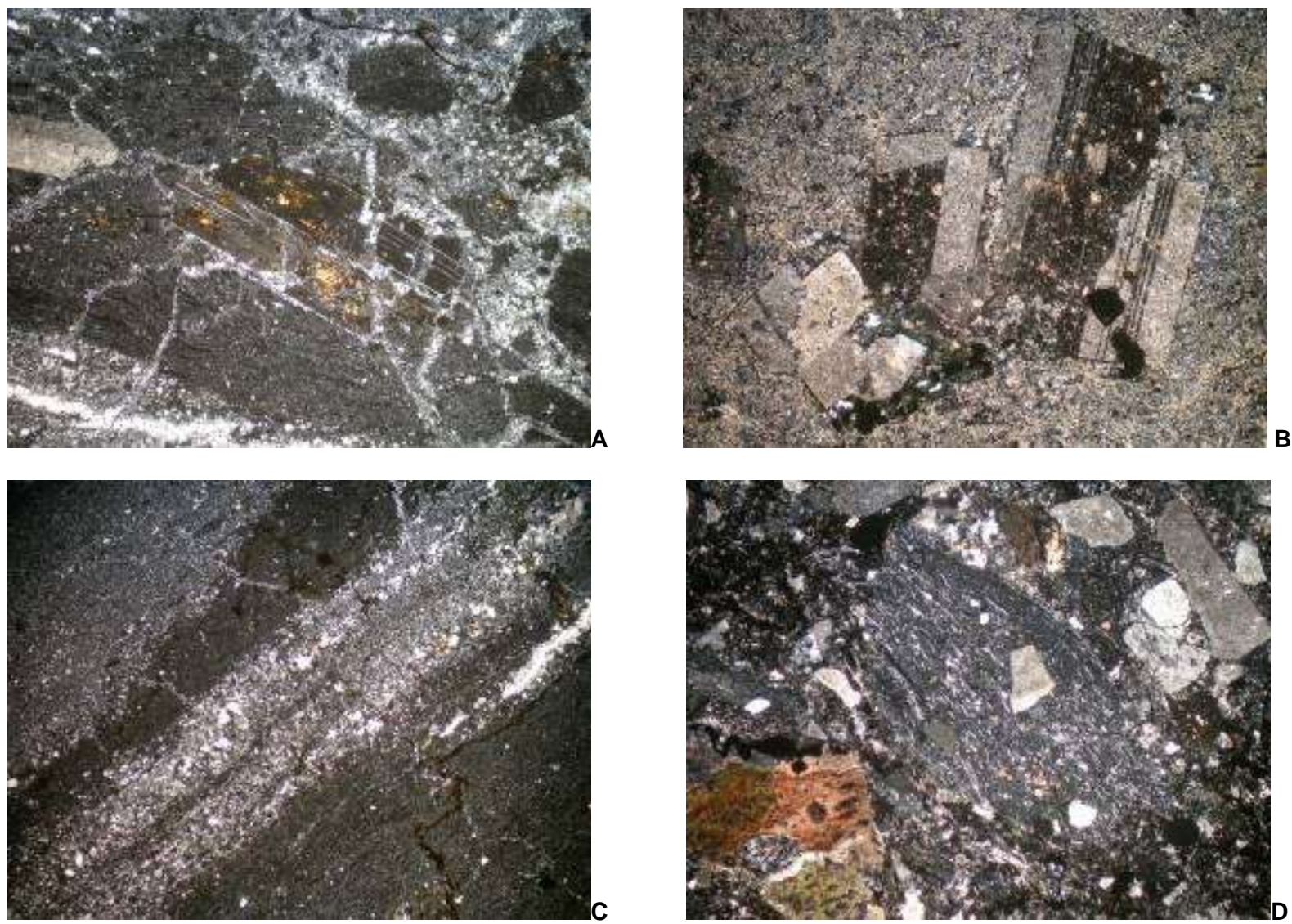

Figure 8. Microscopic investigation of the studied Dokhan volcanics,

A, B. Porphyroblasts of plagioclase embedded in crystal lapilli tuffs, C.N. X10

C. Flow banding in rhyodacite-dacite C.N. X20

D. Lithic and crystal fragments embedded in fine grained groundmass, C.N. X20
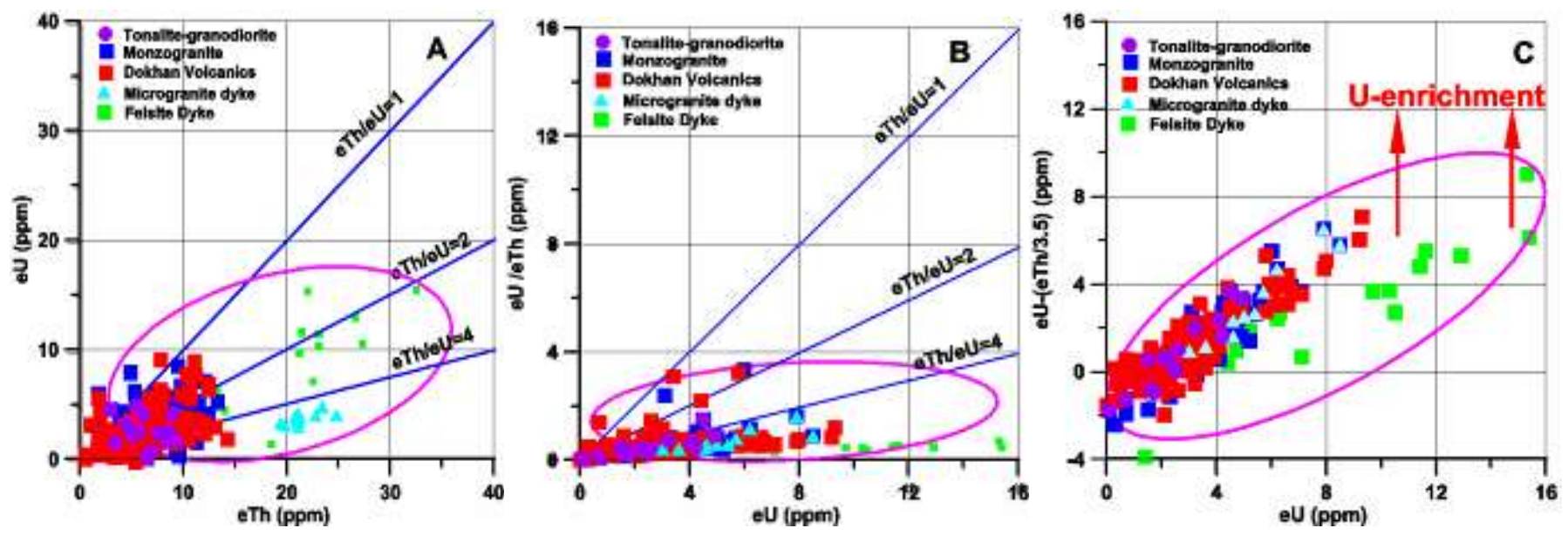

Figure 9. Radioactive elements plot for ground gamma-ray spectrometry measurements for the studied tonalite-granodiorite, monzogranite, Dokhan volcanics, microgranite dyke and felsite dyke
A) eTh versus eU,
B) eU versus eU/eTh and
C) Mobility. 
046 Int. Res. J. Geol. Min.

Table1. Radiometric measurements data for the studied granitic, Dokhan volcanics and the associated dykes at Hadarba area

\begin{tabular}{|c|c|c|c|c|c|c|c|c|c|c|c|c|}
\hline \multirow[t]{2}{*}{ Rock type } & \multicolumn{3}{|c|}{ Total Count } & \multicolumn{3}{|c|}{ K (\%) } & \multicolumn{3}{|c|}{$\mathrm{eU}(\mathrm{ppm})$} & \multicolumn{3}{|c|}{ eTh(ppm) } \\
\hline & Min. & Max. & Aver. & Min. & Max. & Aver. & Min. & Max. & Aver. & Min. & Max. & Aver. \\
\hline $\begin{array}{l}\text { Tonlaite- } \\
\text { granodiorite }(\mathrm{N}=85)\end{array}$ & 12.2 & 19.8 & 15.4 & 2.1 & 2.7 & 2.4 & 1.2 & 2.7 & 1.4 & 5.8 & 8.8 & 7.3 \\
\hline $\begin{array}{l}\text { Monzogranite }(\mathrm{N}=1 \\
21)\end{array}$ & 6.3 & 28 & 17.7 & 1 & 4.9 & 3.41 & 1.1 & 8.5 & 3.46 & 1.3 & 13. 3 & 7.6 \\
\hline $\begin{array}{l}\text { Dokhanvolcanics } \\
(\mathrm{N}=111)\end{array}$ & 2.4 & 43.2 & 20.21 & 0.6 & 10.1 & 4.32 & 1.3 & 9.3 & 3.79 & 0.5 & 14.3 & 7.1 \\
\hline $\begin{array}{l}\text { Microgranite } \\
\text { dyke( }(\mathrm{N}=65)\end{array}$ & 8.5 & 22.2 & 15.35 & 2.5 & 4.9 & 3.7 & 1.9 & 4.6 & 3.25 & 3.9 & 12.1 & 8 \\
\hline $\begin{array}{l}\text { Felsite } \\
(\mathrm{N}=73)\end{array}$ & 8.5 & 49.1 & 34.31 & 1 & 6.5 & 4.92 & 1.4 & 15.4 & 8.24 & 3.9 & 32.5 & 18.6 \\
\hline Basic dyke $(\mathrm{N}=90)$ & 2.4 & 4.4 & 3.4 & 0.8 & 1 & 0.9 & 0.3 & 4.4 & 2.35 & 0.4 & 2.1 & 1.3 \\
\hline Quartz vein $(\mathrm{N}=65)$ & 3.2 & 5.2 & 4.2 & 0.8 & 1.3 & 1.05 & 0.2 & 0.8 & 0.5 & 0.3 & 2.3 & 1.3 \\
\hline
\end{tabular}

\section{Rhyodacite-dacite}

Rhyodacite-dacite shows flow structures and banding. These rocks contain phenocrysts of quartz plagioclase, sanidine embedded in microcrystalline groundmass of quartz, plagioclase, sanidine and hornblende. Chlorite and epidote occur as secondary minerals, whereas zircon, apatite and iron oxides (Fig.8C).

\section{Lithic lapilli tuffs}

These rocks are composed of lithic and crystal fragments embedded in a fine grained groundmass of plagioclase, orthoclase and quartz. The crystals are formed of feldspar and quartz while the lithic fragments are made of rhyodacite and dacite porphyry (Fig.8D).

\section{Crystal tuffs}

They are consist of quartz and plagioclase phenocrysts set in a fine grained groundmass composed of plagioclase and quartz.

\section{Agglomerate}

Agglomerate is large, coarse, rock fragments associated with lava flow. These rock fragments are composed of granitic rocks of various sizes and degrees of angularity.

\section{RADIOMETRIC INVESTIGATION}

Regional field radiometric measurements revealed that the eU reaching up to $2.7 \mathrm{ppm}$ in the tonlaitegranodiorite, up to $8.5 \mathrm{ppm}$ in the monzogranite, up to 9.3 $\mathrm{ppm}$ in the Dokhan volcanics, while reaching up to 15.4 $\mathrm{ppm}$ in the felsite dykes. The statistical treatment of spectrometric data was expressed on binary diagrams of
eTh versus eU, eU versus eU/eTh and eU versus eUeTh/3.5 (Fig.9).These figures indicate that the tonlaitegranodiorite, biotite-muscovite granite and Dokhan volcanic show low uranium content except the felsite dyke which shows slightly high uranium content. Radiometric data for tonlaite-granodiorite, monzogranite, Dokhan volcanics, microgranite dykes and felsite dyke are listed in Table (1).

\section{MATERIALS AND METHODOLOGY}

Thirty samples from the best exposures of the granitic and volcanic from Hadarba area were collected for this study. From these, 21 samples were selected for thin sections to study the mineral constituents of this granite and Dokhan volcanics. Four samples of the monzogranite granite and five samples of the Dokhan volcanic were selected and chemically analyzed for their major oxides and trace elements. The trace elements were analyzed by X-ray fluorescence analyzer (XRF). The analyses were performed in the Nuclear Materials Authority Analytical Laboratories. Data of the major oxides and trace elements are listed in Table (2).

\section{Geochemistry}

The geochemistry of the studied area is focused mainly on the monzogranite and the Dokhan volcanics of the Hadarba area to clarify their chemical classification, chemical affinity, magma type and tectonic setting.

\section{Chemical classification}

The classification of the studied monzogranite and the Dokhan volcanic were chemically confirmed by plotting the analyses on $\mathrm{SiO}_{2}$ versus alkalis diagrams after Middlemost, (1985) and Cox et al.,(1979) (Figs.10and11). 
Table 2. Major oxides (\%) and trace element contents (ppm) of the studied monzogranite and Dokhan volcanics

\begin{tabular}{|c|c|c|c|c|c|c|c|c|c|}
\hline \multirow{3}{*}{ S. No. } & \multicolumn{4}{|c|}{ Monzogranite } & \multicolumn{5}{|c|}{ Dokhan volcanics } \\
\hline & \multirow[b]{2}{*}{14} & \multirow[b]{2}{*}{15} & \multirow[b]{2}{*}{27} & \multirow[b]{2}{*}{40} & \multicolumn{2}{|c|}{ Rhyolite } & \multicolumn{3}{|c|}{ Dacite } \\
\hline & & & & & 4 & 37 & 5 & 6 & 9 \\
\hline $\mathrm{SiO}_{2}$ & 75.66 & 74.55 & 72.57 & 73.01 & 72.44 & 69.91 & 63.83 & 62.90 & 65.39 \\
\hline $\mathrm{TiO}_{2}$ & 0.21 & 0.18 & 0.20 & 0.18 & 0.35 & 0.42 & 0.88 & 0.45 & 0.12 \\
\hline $\mathrm{Al}_{2} \mathrm{O}_{3}$ & 12.48 & 12.60 & 12.58 & 12.37 & 12.18 & 12.01 & 12.64 & 13.95 & 13.90 \\
\hline $\mathrm{Fe}_{2} \mathrm{O}_{3}$ & 1.26 & 1.59 & 3.39 & 2.99 & 4.50 & 5.07 & 9.18 & 5.79 & 8.65 \\
\hline MnO & 0.02 & 0.06 & 0.04 & 0.03 & 0.10 & 0.15 & 0.11 & 0.40 & 0.18 \\
\hline $\mathrm{MgO}$ & 0.40 & 0.71 & 0.40 & 0.81 & 0.60 & 0.81 & 1.61 & 1.01 & 0.50 \\
\hline $\mathrm{CaO}$ & 0.68 & 1.66 & 1.68 & 1.96 & 1.68 & 3.36 & 4.21 & 2.80 & 2.40 \\
\hline $\mathrm{Na}_{2} \mathrm{O}$ & 4.25 & 4.75 & 4.95 & 3.79 & 1.85 & 4.85 & 5.59 & 5.05 & 0.61 \\
\hline $\mathrm{K}_{2} \mathrm{O}$ & 4.83 & 3.45 & 3.45 & 2.64 & 5.59 & 2.57 & 1.61 & 2.24 & 5.42 \\
\hline $\mathrm{P}_{2} \mathrm{O}_{5}$ & 0.07 & 0.08 & 0.11 & 0.05 & 0.04 & 0.14 & 0.16 & 0.14 & 0.26 \\
\hline LOI & 0.14 & 0.37 & 0.60 & 2.20 & 0.67 & 0.71 & 0.17 & 5.27 & 2.25 \\
\hline Total & 100.0 & 100.0 & 99.97 & 100.03 & 100.0 & 100.0 & 99.99 & 100.0 & 99.67 \\
\hline \multicolumn{10}{|c|}{ Trace elements (ppm) } \\
\hline $\mathrm{Cr}$ & 71 & 41 & 27 & 34 & 22 & 13 & 8 & 12 & 20 \\
\hline $\mathrm{Ni}$ & 7 & 6 & 4 & 6 & 4 & 3 & 6 & 4 & 3 \\
\hline v & u.d & 4 & 7 & 5 & 7 & 48 & 132 & 32 & 4 \\
\hline $\mathrm{Cu}$ & 10 & 7 & 19 & 8 & 15 & 20 & 14 & 16 & 19 \\
\hline $\mathrm{Pb}$ & u.d & u.d & 11 & u.d & 39 & u.d & 87 & 51 & u.d \\
\hline $\mathrm{Zn}$ & 74 & 46 & 20 & 41 & 67 & 124 & 145 & 140 & 28 \\
\hline $\mathbf{R b}$ & 112 & 86 & 97 & 95 & 116 & 60 & 44 & 73 & 201 \\
\hline $\mathrm{Ba}$ & 144 & 278 & 224 & 592 & 230 & 375 & 581 & 421 & 126 \\
\hline $\mathrm{Sr}$ & 6 & 7 & 321 & 5 & 884 & 747 & 894 & 1449 & 1807 \\
\hline $\mathrm{Ga}$ & 22 & 25 & 24 & 22 & 23 & 23 & 22 & 22 & 22 \\
\hline $\mathrm{Nb}$ & 61 & 61 & 13 & 10 & 10 & 9 & 9 & 9 & 9 \\
\hline $\mathrm{Zr}$ & 215 & 227 & 112 & 172 & 308 & 254 & 286 & 451 & 586 \\
\hline $\mathbf{Y}$ & 145 & 153 & 8 & 117 & 22 & 19 & 22 & 31 & 39 \\
\hline
\end{tabular}

On $\mathrm{SiO}_{2}$ versus alkalis diagram after Middlemost, (1985) the monzogranite samples fall in the granite field, while on $\mathrm{SiO}_{2}$ versus alkalis diagram after Cox et al., (1979) the Dokhan volcanic samples fall in the rhyolite and dacite fields.

\section{Alkaline affinity}

In the $\mathrm{SiO}_{2}$ versus $\mathrm{Na}_{2} \mathrm{O}+\mathrm{K}_{2} \mathrm{O}$ diagram (Fig. 12), after Irvine and Baragar (1971) all the monzogranite and the Dokhan volcanic samples show subalkaline affinity.

\section{Tectonic setting}

On the $\mathrm{Rb}$ versus $(\mathrm{Y}+\mathrm{Nb}$ ) diagram (Fig. 13), after Pearce et al. (1984) the monzogranite samples fall in the within plate granites (WPG) field.
Ewart (1979 and 1981) suggested various discrimination diagrams to identify the modern tectonic environments (Fig. 14). The plots of studied Dokhan volcanic samples on $\mathrm{SiO}_{2}$ versus $\mathrm{Zr}$ binary diagram indicate that, most samples fall within immature island arcs field except one sample occurs in the active continental margin field.

\section{Trace elements}

In primitive-mantle normalized spidergram (Fig. 15), the monzogranite is enriched in some LILE (large ion lithophile elements) ( $\mathrm{Rb}, \mathrm{Sr}, \mathrm{Ba}, \mathrm{K})$ and HFSE (high field strength elements) ( $\mathrm{Zr}, \mathrm{Y}, \mathrm{Nb})$, but strongly depleted in $\mathrm{Ni}, \mathrm{Cr}$ and $\mathrm{Pb}$.

Relative to normal mid-ocean ridge basalts (N-MORB), the studied Dokhan volcanics (Fig. 16) show enrichment in the strongly incompatible LILE (large ion lithophile 


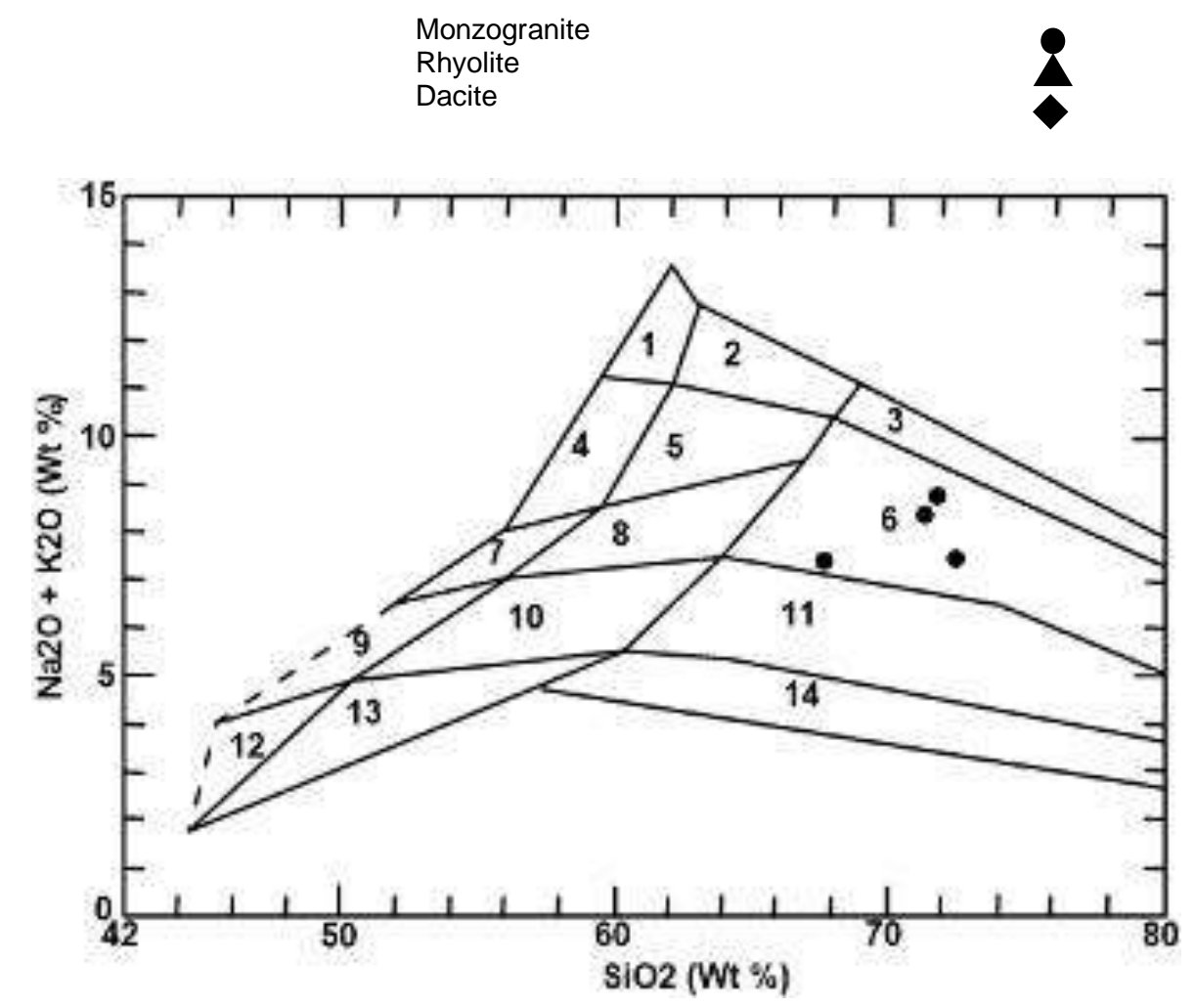

Figure10. $\mathrm{SiO}_{2}$ versus alkalis diagram for the studied monzogranite after Middlemost (1985). Granite field (6)

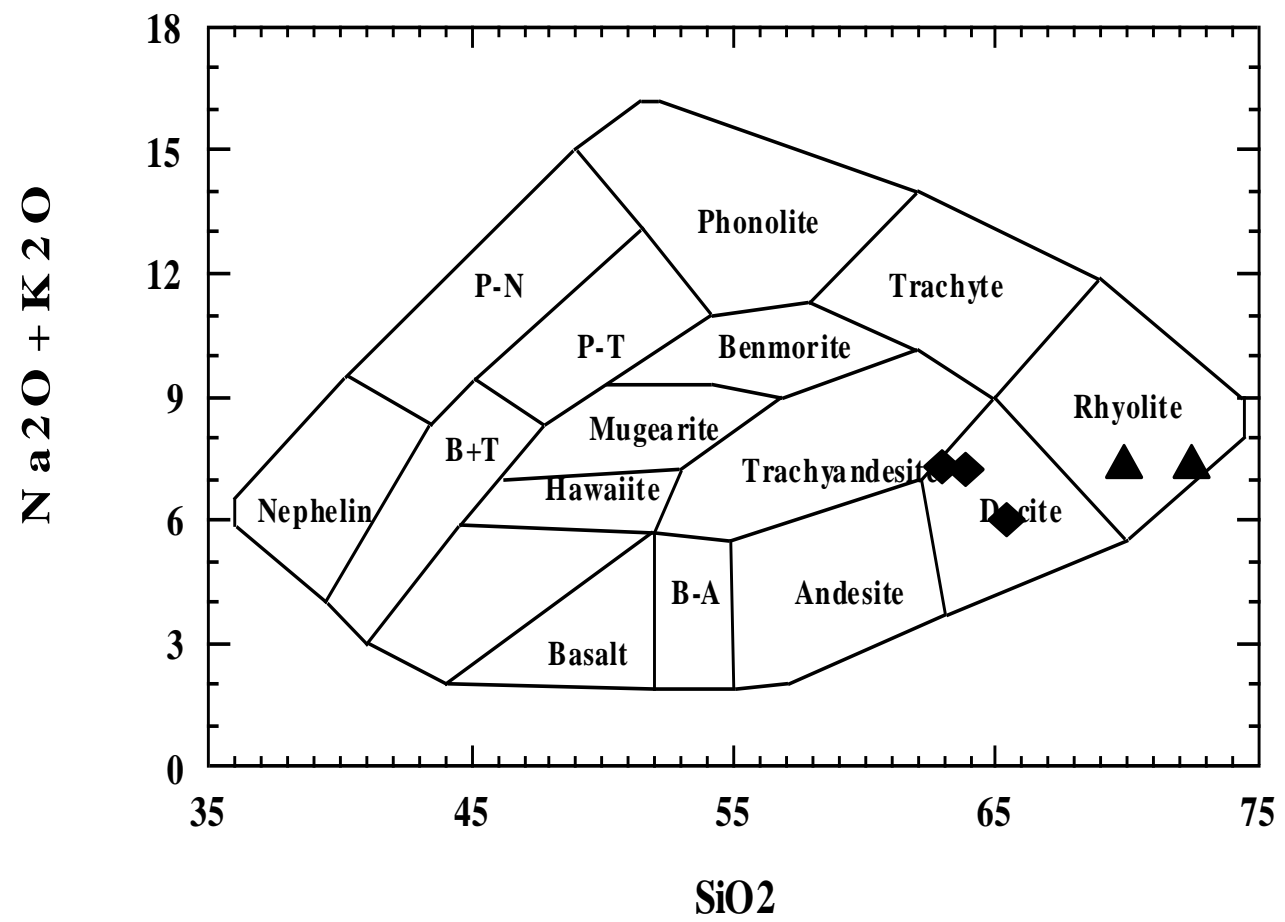

Figure 11. $\mathrm{SiO}_{2}$ versus alkalis diagram for the studied Dokhan volcanics after Cox et al. (1979).

The symbols are the same as those in Fig. (8). 


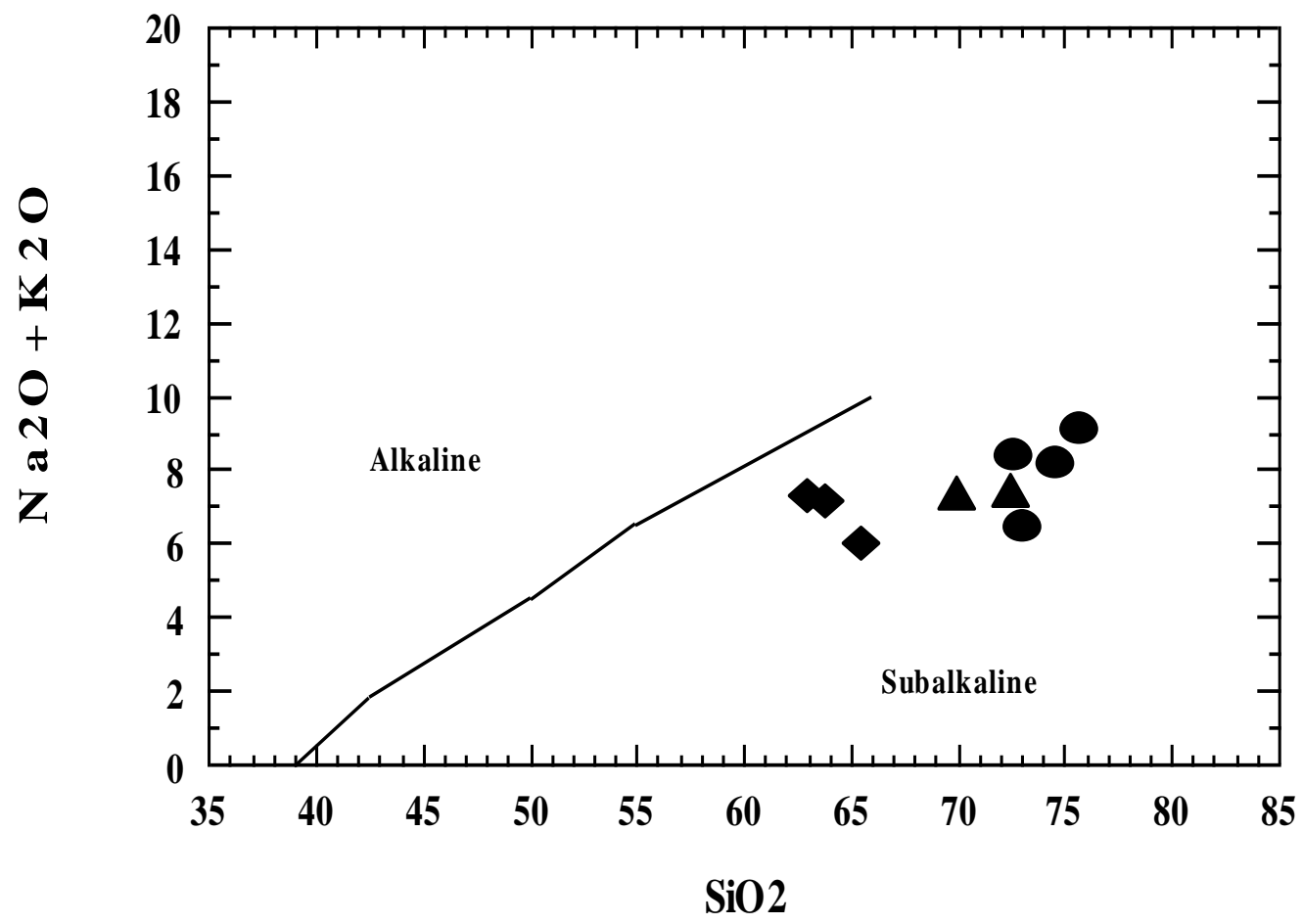

Figure12. $\mathrm{SiO} 2$ versus $\mathrm{Na}_{2} \mathrm{O}+\mathrm{K}_{2} \mathrm{O}$ diagram for studied monzogranite and the Dokhan volcanics, after Irvine and Baragar (1971).

Symbols as in Fig. (8).

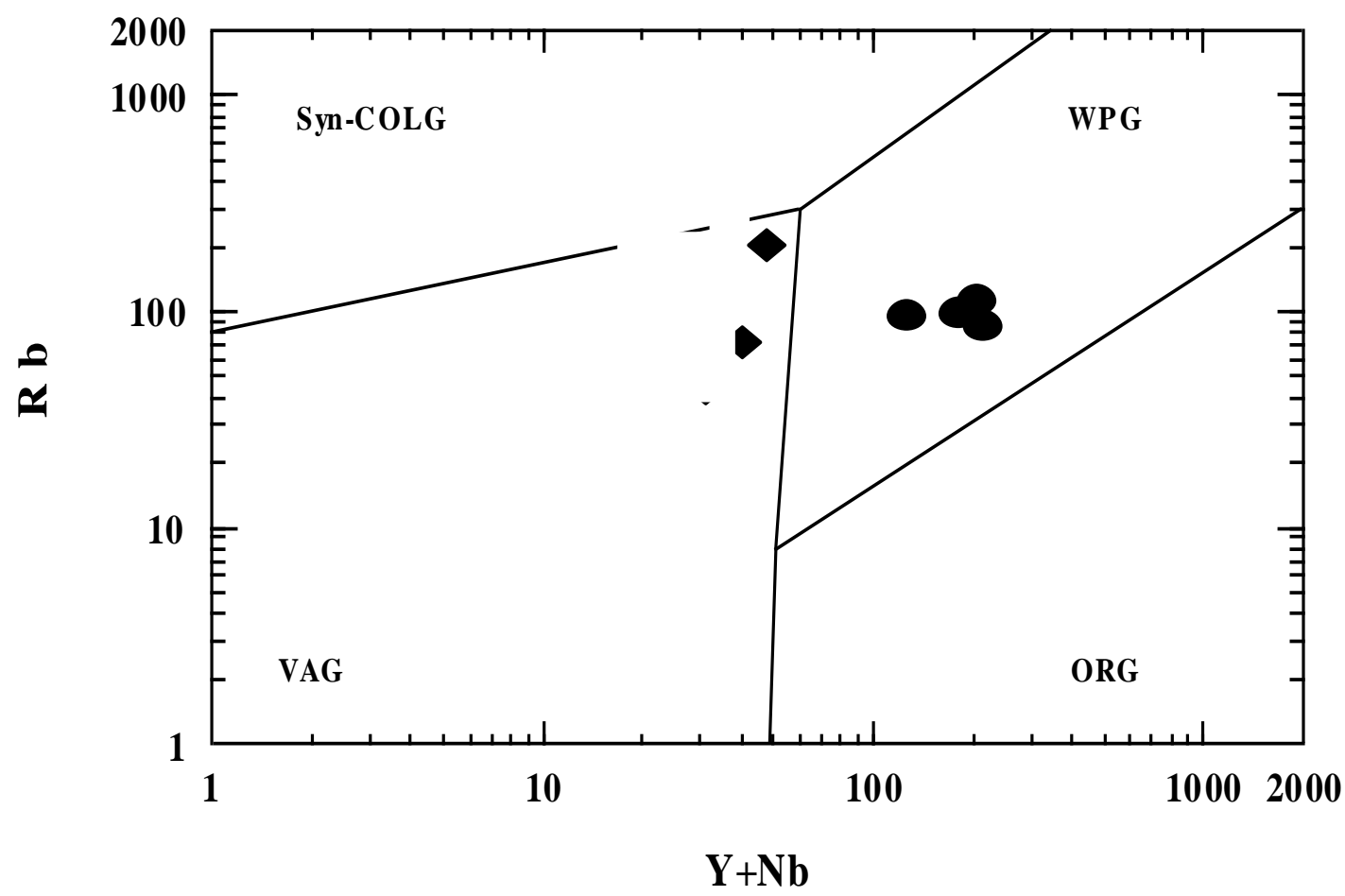

Figure13. $\mathrm{Rb}-\mathrm{Y}+\mathrm{Nb}$ tectonic discrimination diagram for the studied monzogranite, Syn-collision ( Syn- COLG), volcanic arc granites ( VAG ), within plate granites (WPG) and ocean ridge granites ( ORG ), after Pearce et al. (1984).

Symbols as in Fig. (8). 


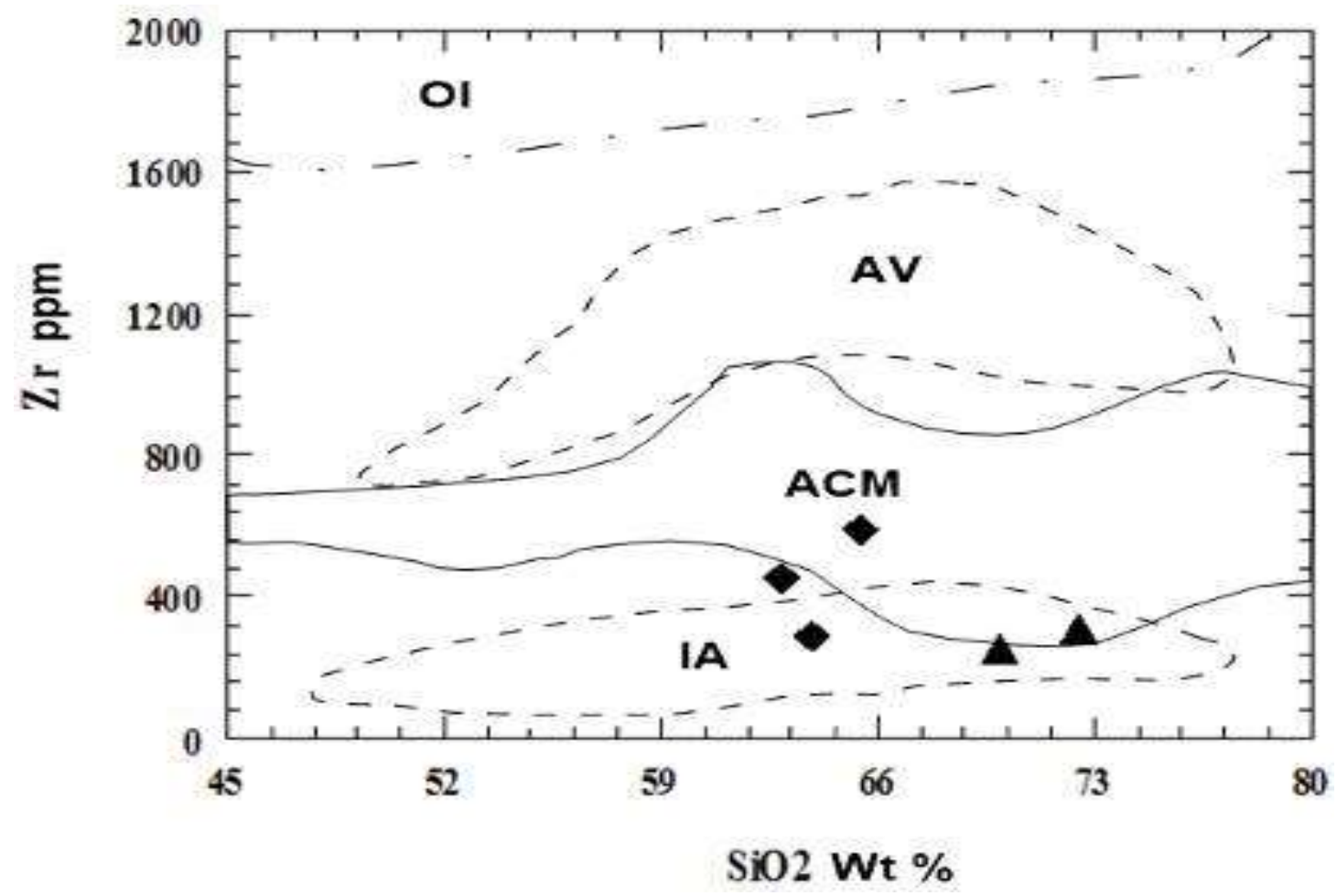

Figure14. $\mathrm{SiO}_{2}-\mathrm{Zr}$ binary diagram for the studied Dokhan volcanics, after Ewart (1979 \& 1981). OI= Oceanic islands, $A V=$ Anorogenic volcanic terrains, $A C M=$ Active continental margins, $I A=I m m a t u r e$ island arcs.

Symbols as in Fig. (8).

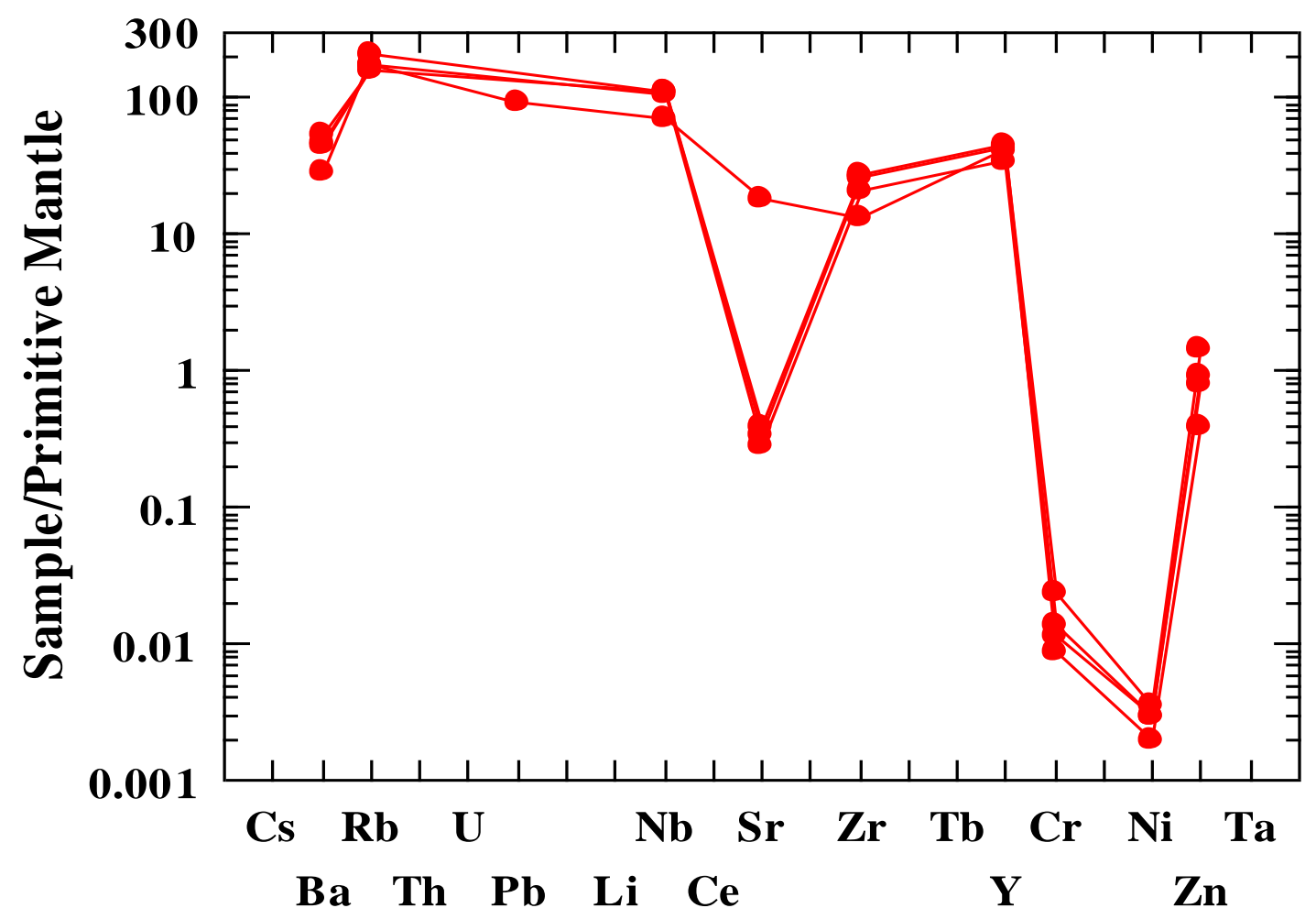

Figure 15. Primitive-mantle (PM) normalized spidergram for the studied monzogranite. The PM values are from Sun and McDonough (1989) 


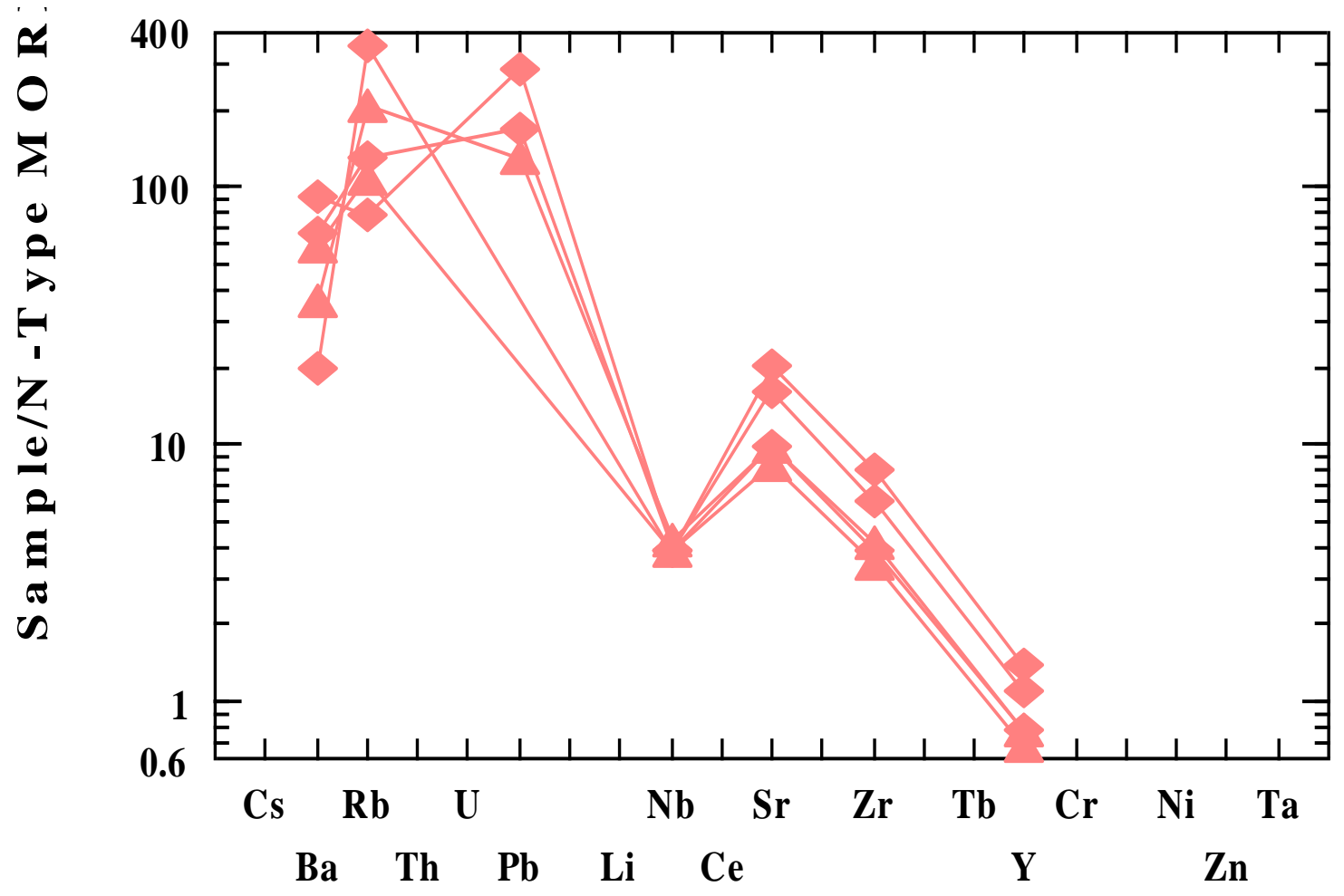

Figure 16. N-MORB-normalized spidergram for the studied Dokhan volcanics

elements) such as $\mathrm{Rb}, \mathrm{Ba}$, and $\mathrm{Sr}$ and HFSE (high field strength elements) such as $\mathrm{Zr}, \mathrm{Y}$, but strongly depletion in $\mathrm{Nb}, \mathrm{Ni}, \mathrm{Cr}$ and $\mathrm{Pb}$.

\section{CONCLUSION}

Granitic and volcanic rocks are widely occurring at Hadarba area. The acid plutonic rocks comprise tonalitegranodiorite and monzogranite, while acid volcanic rocks include Dokhan volcanics which composed of rhyolite, rhyodacite and dacite. Field studies indicate that Dokhan volcanics extrude both tonalite-granodiorite and monzogranite with sharp contact forming a thick successive sequence of laminated acid lava flows, crystal lapilli tuffs and agglomerates. They have composition range from rhyolite, rhyodacite to dacite. These rocks are characterized by high concentrations of $\mathrm{SiO}_{2}, \mathrm{Na}_{2} \mathrm{O}$, $\mathrm{Fe}_{2} \mathrm{O}_{3}, \mathrm{~K}_{2} \mathrm{O}, \mathrm{Zr}$, Nb and $\mathrm{Y}$ but low in $\mathrm{MgO}, \mathrm{CaO}, \mathrm{Cr}, \mathrm{Ni}$, $\mathrm{Sr}, \mathrm{Ga}$ and $\mathrm{V}$. Shear zone comprises line-arranged intrusions trending NE-SW direction and extends for about $2.3 \mathrm{~km}$ length with a wide reaches up to 10 meter cutting in the mozogranite. The spectrometric measurements for this shear indicate low uranium content. Petrochemical studies and tectonic discrimination diagrams for the monzogranite reveal that it is classified as granite developed in the within-plate tectonic environment, while Dokhan volcanics are classified as rhyolite and dacite developed in the immature island arcs and active continental margin environments.

Field radiometric measurements of these granitic and volcanic rocks reveal low uranium and thorium contents. Uranium contents range from 1.2 to $2.7 \mathrm{ppm}$ in the tonalite-granodiorite, from 1.1 to $8.5 \mathrm{ppm}$ in the monzograniteand from 1.4 to $15.4 \mathrm{ppm}$ in the felsite dyke.

\section{REFERENCES}

Abdel Rahman AM (1996). Pan-African volcanism: petrology and geochemistry of the Dokhan Volcanic suite in the northern Nubian Shield. Geol Mag. 133:17-31.

Abu El-Leil I, Hassaan M, Abdel Tawab M, Abdel Rahman H (1990). Geological and Geochemical studies on the Feirani group: The proposed Late Proterozoic younger volcanic rocks, Sinai, Egypt. J. Mineralogical Society of Egypt (ISSN-1110 - 1466), 2:61-80.

Alaabed S, El Tokhi M (2014). Mineralogical and geochemical aspects of the petrogenesis of Pan African Dokhan volcanics at Esh El Mellaha Area-NE Desert, Egypt. Arabian J. Geosci. 7(12):55535568.

Ball J (1912). The geography and geology of South eastern Egypt. Geol. Surv., Cairo P. 394.

Basta EZ, Kotb H, Awadalla MF (1980). Petrochemical and geochemical characteristics of the Dokhan Formation at the type locality, Jabal Dokhan, Eastern Desert, Egypt. Inst. Appl. Geol. Jeddah Bull 3:121-140.

Cox KG, Bell JD, Pankhurst RJ (1979). The interpretation of igneous rocks. London: Allen and Unwin. 
El Alfy Z, Bagddady M, Awaga G, Morsei A, Ramadan T, Abdallah MA (1994). Geochemical exploration of Elba - Gerf area South Eastern Desert, Egypt, Geol. Surv. Cairo (unpublished report).

Egyptian Geological Survey (1999). The basement rocks of Gabal Elba Quadrangle, Scale, 1:250,000. Geol. Surv. Egypt, Cairo.

El Gaby S, Khudeir AA, El Taky M (1989). The Dokhan volcanics of Wadi Queih area, central Eastern Desert, Egypt. In: Proceedings of the 1st Conference on Geochemistry, Alexandria University, Egypt, 42-62.

El Gaby S, List FK, Tehrani R (1990). The basement complex of the Eastern Desert and Sinai. In: Said, R. (Ed.), The Geology of Egypt. Balkema Rotterdam, The Netherlands. 175-184.

Eliwa HA (2000): Petrology, geochemistry, mineral chemistry and petrogenesis of Samr El-Qaa volcanics, North Eastern Desert, Egypt. Sci. J. Fac. Sci. Minufiya Univ. 14:1-45.

Eliwa HA, Kimura JI, Itaya T (2006). Late Neoproterozoic Dokhan volcanics, North Eastern Desert, Egypt: Geochemistry and petrogenesis. Precambrian Research, 151(1-2): 31-52.

El Sayed MM, Obeid MA, Furnes H, Moghazi AM (2004). Late Neoproterozoic volcanism in the Southern Eastern Desert, Egypt: petrological, structural and geochemical constraints on the tectonic-magmatic evolution of the Allaqi Dokhan volcanic suite. $\mathrm{N}$. Jb. Miner. Abh. 180 (3):261-286.

Ewart A (1979). A review of the mineralogy and chemistry of the Tertiary-Recent dacitic,latitic, rhyolitic and related salic volcanic rocks. In: Trondhjemites dacites and related rocks (ed. BARKER, F.) Elsevier, Amsterdam, 13-121.

Ewart A (1981). The mineralogy and petrology of Tertiary-Recent orogenic volcanic rocks: with special reference to the andesiticbasaltic compositional range. In: Andesites (ed.THORPE, J.) Elsevier, Amsterdam.

Fitches WR, Graham RH, Hussein IM, Ries AC, Shackleton RM, Rice RC (1983). The Late Proterozoic ophiolite of Sol Hamed, NE Sudan Precambrian Res. 19: 385 - 441, Elsevier Amsterdam.

Fritz H, Wallbrecher E, Khudeir AA, Abu El Ela FF, Dallmeyer DR (1996). Formation of Neoproterozoic metamorphic core complexes during oblique convergence Eastern Desert, Egypt. J. Afr. Earth Sci. 23: 311-329.

Hassan MA, Hashad AH (1990). Precambrian of Egypt. In: Said, R. (Ed.), The Geology of Egypts. Alkema, Rotterdam, 201-245.

Hume WF (1934). Geology of Egypt. II. The fundamental Precambrian rocks of Egypt and Sudan: Part I, The metamorphic rocks: 1-300; Part II, The later plutonic and minor intrusive rocks: 301-688; Part III, the minerals of economic value: Geol. Surv. Egypt. 689-900.

Hussein IM (1977).: Geology of the Halaib Area of the Northern Red Sea Hills, Sudan, With Special Reference to the Sol Hamid Basic Complex, M. Phil. Thesis, Portsmouth Polytechnic. Pp 175.

Irvine TN, Baragar WRA (1971). A guide to the chemical classification of the common volcanic rocks, Canadian J. Earth Sci. 8:523 - 548.

Khalaf EA (2010). Origin and evolution of post-collisional volcanism: an example from Neoproterozoic Dokhan volcanics at Gabal Nugara area, Northeastern Desert, Egypt. Arabian J. Geosci. 5(4):663-695.

Khaliad AM, Eissa MM, Hanafy AM, Moselhy NE (1997). Results of geochemical, geological and mineralogical exploration of Gebel Elba, Southeast Egypt. Geol. Surv., Cairo (unpublished report).

Middlemost EAK (1985). Magma and magmatic rocks, Longman Group Limited Essex.

Mohamed FH, Moghazi AM, Hassanen MA (2000). Geochemistry, petrogenesis and tectonic setting of late Neoproterozoic Dokhantype volcanic rocks in the Fatira area, Eastern- Egypt. Int. J. Earth Sci. 88:764-777.

Moghazi AM (2003). Geochemistry and petrogenesis of a high-K calcalkaline Dokhan volcanic suite, South Safaga area, Egypt: the role of late Neoproterozoic crustal extension. Precamb. Res. 125:161178.

Nasr BB, Youssef M (1995). New occurrences of Tertiary alkaline rocks at Gebel Elba area South Eastern Desert, Egypt. Annals of Geol. Surv. 5(20):871 - 873 .

Nasr BB, El Sherbeni H (1998). New occurrences of Dokhan-type volcanics in the Halaib area, South Eastern Desert, Egypt. Annals of Geol. Surv. 5(21):23 - 33.

Omar MA, Said SM, Morsi AM, Abu EL Labn SA (1998). Geochemical map sheet No. 36 NE L 1,2,3 Qash Amir area, South Eastern Desert, Egypt. Geol. Surv. , Cairo (unpublished report).

Pearce JA, Harris NB, Tindle AG (1984). Trace element discrimination diagrams for the tectonic interpretation of granitic rocks; J. Petrology. 25:956-984

Ressetar R, Monard JR (1983). Chemical composition and tectonic setting of the Dokhan Volcanic formation, Eastern Desert, Egypt. J. Afr. Earth Sci. 1: 103-112.

Stern RJ, Gottfried D (1986). Petrogenesis of late Precambrian (575$600 \mathrm{Ma}$ ) bimodal suite in northeast Africa. Contrib. Mineral Petrol., 92: $492-501$

Stern RJ (1994). Arc assembly and continental collision in the Neoproterozoic East African Orogen: implications for the consolidation of Gondwanaland. Ann. Rev. Earth Planet. Sci. 22: 319-351.

Stern RJ, Gottfried D, Hedge CE (1984). Late Precambrian rifting and crustal evolution in the northeast Desert of Egypt. Geology 12: 168-172

Stern RJ, Sellers G, Gottfried D (1988). Bimodal dyke swarms in the North Eastern Desert of Egypt: significance for the origin of late Precambrian "A-type" granites in northern Afro-Arabia. In: El Gaby, S., Greiling, R.O. (Eds.), The Pan-African Belt of Northeast Africa and Adjacent Areas. Vieweg, Weisbaden, Pp147-177.

Sun SS, McDonough WF (1989). Chemical and isotopic systematics of oceanic basalts; implications for mantle composition and processes. In: Magmatism in the ocean basins. Saunders, A.D. and Norry, M.J. (Editors), Geological Society of London, London. 42: $313-345$

\section{How to cite this article:}

Hassan A. A. Shahin, Masoud S. Masoud and Moustafa

M. Bayoumi. Geology, Geochemistry and Radioactivity of Granitic and Volcanic Rocks at Hadarba Area, South

Eastern Desert, Egypt. Int. Res. J. Geol. Min. 6(2):038-052 